\title{
Mobile-Based E-Sociometry Application Development at the Counseling Guidance Laboratories of the State Islamic Institute (IAIN) Bukittinggi
}

\author{
Rezza Shafitri Anita1,*, Sarwo Derta \\ 1,2Informatics and Computer Engineering Education IAIN Bukittinggi, Bukittinggi, Indonesia
}

\section{Article Information}

Article History:

Accepted by the Editor: May 17, 2021

Final Revision: June 29, 2021

Published Online: June 30, 2021

\section{Keywords}

\section{Sociometry}

Mobile

R\&D

Waterfall

\section{Correspondence}

E-mail: rezhashafitrianita@gmail.com*

\section{A B S T R A C T}

Sociometry is something that can be used in studying the structure of social relations among a group of individuals on the basis of research on social relations and social status of each member of the group concerned. Currently the service of sociometric instruments in the guidance and counseling laboratory of the Bukittinggi State Islamic Institute is still using conventional techniques using Ms.Excel. It is done manually using the distribution of questionnaires, Ms.Excel, which is still combined with Ms.Acces, which is not online yet, so that it can only be distributed in labor, and the next problem is that the application that uses Ms.Excel cannot yet display sociometric reports graphically. The research method that the author uses is the R\&D Research \& Development method with a waterfall SDLC (System Development Life Cycle) system development model consisting of the Communication.Planning.Modeling stages. Construction.Deployment. For the product test that the author did, the results obtained: the validity test by the validator obtained a value of 0.85 with valid criteria, the practicality test by the practitioner obtained a value of 0.83 with the Very Practical criteria, and the effectiveness test by the effectivator obtained a value of 0.75 with the Very Effective criteria.

This is an open access article under the CC-BY-SA license

\section{Introduction}

PT. The development of IT that is currently happening in human life really cannot be denied anymore, starting from the system of technological development, robotics, and computerization that has penetrated all sectors of the line of life. Its development runs so rapidly, making it easier for humans to develop and create all forms of sophisticated technology to help all forms of activities and human routines to carry out daily life.

With these technological advances, it is very easy for humans to do various things, not only for worldly affairs such as socializing and communicating with fellow humans but also helping humans get closer to the creator of Allah SWT. Thus humans are greatly helped by the grace given by Allah SWT with the ease of progress and development of the technology. Allah SWT says in the Qur'an Surah Ar-Rahman verse 33, namely:

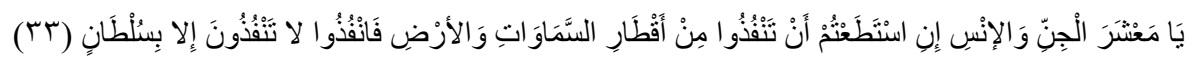


Meaning: "O congregation of jinn and humans, if you are able to penetrate across) the corners of the heavens and the earth, then cross it, you cannot penetrate it except from strength." (Surah Ar-Rahman: 33).

The translation of the verse above explains some of the things contained in the meaning of these verses. It includes the meaning of the word sulthan, which means it has many meanings, such as strength and power, knowledge, ability and others. While the meaning that is the point of the discussion above is spaciousness and spaciousness in understanding science. [1]

In the book Al-Muslimun wa al-ilm al-hadist by Abdul Al-Razaq, in the book he defines the word sultan with the meaning of science and the ability to develop technological progress. [2] In the book, he also explained that humans can take advantage of technological developments and advances where humans can explore outer space by utilizing the knowledge they learn and with sophisticated technology.

From the things discussed above, such as future technological developments, the Qur'an does not provide clear or detailed explanations and explanations, so it is rather difficult to find a theoretical basis from within the Qur'an. However, the Qur'an provides an opportunity and ability of the human mind to understand it verses to explain it, especially about how to take advantage of and use the development of this technology. Because God has given reason to humans where humans have been appointed as Caliphs on earth who are tasked with managing and providing prosperity on earth; thus humans are the most noble creatures that God has created on earth from other creatures. [2]

The interpretation of the verse above is the progress and development of science that has been studied by humans and has the ability in that field; humans must be able and keep trying to develop further and expand the knowledge that has been studied without limits. Thus humans must also prepare the maximum preparations to achieve all of these things as explained in the Qur'an. All forms of business and actions that we will face must have plans and preparations as much as possible so that what is planned can be achieved and not in vain. in vain, where all the preparations are skills and also in-depth knowledge in technology and communication sciences. Without this ability, humans cannot achieve what they expect. Therefore, humans must always strive and strive to always be enthusiastic in understanding, developing and studying science, technology, information and communication.

Of course, advances in technology and information have penetrated into various sectors of human life, one of which is in the education sector. Thus in the world of education to improve the quality of education in a country, the role of technology, for now, has become very important and cannot be avoided by utilizing technological advances in the field of education, it can improve the quality and effectiveness of the learning process, so that the goal of learning can be achieved.

The use of technology in education has touched all sectors, including guidance and counseling. Through Law No. 20 of 2003 concerning the national education system, the use of technology should be highly optimized, especially for counselors [3]. With the use of this technology, it is hoped that it will make it easier for students to access services that help them receive all forms of guidance and counseling services.

To support the process carried out in guidance and counseling, all parties must try to utilize these technological developments, be it counselors, students, and the community. Having the ability to use technology will greatly facilitate counselors in providing guidance and counseling services to students.

With technological advances in guidance and counseling services, electronic counseling has emerged, called e-counseling. Which with this e-counseling guidance and counseling services can be done electronically which later the process of this counseling service can be done as a whole not only to one individual where this guidance and counseling can be done by utilizing internet technology and utilizing computer equipment and also smartphone as a liaison between counselors and students.

With the existence of technology such as e-counseling, in some time the technology has experienced development, which has created an application that supports the implementation of guidance and 
counseling in Indonesia, namely the E-Sociometry application. Sociometry is a method of how to form the relationship between social structure and psychological well-being. Sociometry itself is aimed at studying how the relationship forms between the group structure of interpersonal relationships that exist within a person. [4]

To find out how the form of social relations between individuals in a group, we can use a technique or method called Sociometry. In this sociometric method, we will use the pattern of how social relationships occur in an individual in a group. The pattern of thinking on each individual in a certain group is different, so to measure the shape of the pattern of each individual, we can see from the structure of the pattern of relationships that occur in the group and can be measured quantitative qualitatively. Sociometry itself functions as a tool to find out how the behavior of each individual in a group is, namely to find out how the pattern will form about the structure of a group so that it can find out how the form of interest of an individual in the group. In education itself, sociometry is used to see how the pattern of relationships between students in a group forms whether the students have an interest, refuse or there is something they like and do not like, and how their difficulties form in creating a social relationship between individuals. one another in a group. [5]

The Bukittinggi State Islamic Institute is one of the higher education institutions that provides laboratories for the guidance and counseling study program. This guidance and counseling education study program has used the sociometric method to obtain student data and also provides guidance and counseling services to students which is a goal to obtain the goals of education.

From the interviews with one of the lecturers, the former head of the BK labor at IAIN Bukittinggi called Ms. Intan. The writer can conclude that data collection and also the guidance and counseling services provided to students have used the sociometric method but are still in manual form, namely When collecting data, the lecturer will provide a distribution of questionnaires to each student. After the students fill out the questionnaire, the lecturer will check the completed questionnaire and collect the data obtained, then input the data into Microsoft Excel then the lecturer will connect and describe every social relationship between each student which is still done manually. In this way, to collect data, the lecturer will take a very long time to collect data and measure how the form of social relations occurs in each student.

The Ms.excel used today is still combined with Ms.access and is still not mobile or online, which is still an individual which can only be distributed on the laboratory computer so that students who bring their own devices or use smartphones cannot access it. Furthermore, as for the next problem, namely the use of sociometry that uses Ms. excel, it still cannot display reports graphically, while the lecturer hopes that in processing sociometric data it can display reports in graph form so that it will make it easier for lecturers to see the structure of individual social relationships between social groups. The writer is interested in designing a mobile-based sociometric application from the whole problem above. This application is expected to help and facilitate the lecturers of counseling guidance courses in accessing and carrying out sociometric tests to determine the level of student relations in the class to be effective and efficient.

\section{Method}

Research In this study the authors use the Research \& Development $(R \& D)$ method which is very suitable to be used to design or develop a product, and also this method has systematic steps in designing a product that we will design, and also tests how the validity, effectiveness and practicality of a product [6]. This study aims to design a product in a mobile-based e-sociometry application in the guidance and counseling laboratory of the State Islamic Institute (IAIN) Bukittinggi.

In this study, the authors use a system development model adopted from the SDLC system life cycle (System Development Life Cyles), which develops or changes a software system using the models and methodologies used by people to develop previous software systems [8]. SDLC has several models, including the Waterfall, Spiral, Iterative, Fountain, Rapid Application Development (RAD) and Build And 
Fix models. From several existing models, the author applies the waterfall model. According to Pressman, the waterfall model is a classical model that is systematic, sequential in building software. The name of this model is actually "Linear Sequential Model." Moreover, this model is often referred to as the "Classic Life Cycle," or the waterfall method is a software development model that emphasizes sequential and systematic phases, starting from the specification of consumer needs and progressing through the planning, modeling, development, and deployment processes, which culminate in on continuous support for a complete software [8].

According to Pressman, the Waterfall Model Development Life Cycle consists of [9]: (1) Communication is the first step starting with communication to consumers or users. This initial step is an important step because it involves gathering information about the needs of consumers or users; (2) Planning is the second step after the communication process, then establishes a plan for software work which includes technical tasks to be carried out, risks that may occur, required resources, results to be made, and work schedule; (3) Modeling, this modeling process translates the requirements into a software design that can be estimated before coding is made. This process focuses on the design of data structures, software architecture, interface representation, and procedural details (algorithms); (4) Construction, is the process of making code (code generation). Coding or coding is the translation of designs in a language that the computer can recognize; and (5) Deployment; this stage can be said to be final in making a software or system. After doing the analysis, design, and coding, the user will use the finished system.

The product design that has been made cannot be used immediately but must be tested first. The product test consists of three stages, namely validity test, practicality test, and effectiveness test. The instrument used is a questionnaire. The author uses these three product test methods so that the resulting product is of high quality and ready to use, it is necessary to have a product test in this study. The product tests to be carried out are as follows.

Validity test aim to undertand how the form product validity acording to conducted research. For this testing stage, the user can use a questionnaire, which refers to the Aikens'V Statistical formula such as the following equation [7].

$$
\begin{aligned}
& \mathrm{V}=\sum \mathrm{s} /[\mathrm{n}(\mathrm{c}-1)][\text { Aiken's } \mathrm{V}] \\
& \text { Description: } \\
& V=\text { Validity Test } \\
& \mathrm{s}=r-l o \\
& r=\text { number given by rater } \\
& l o=\text { the lowest validity research score } \\
& n=\text { number of raters } \\
& C=\text { the highest number of validity research }
\end{aligned}
$$

Practicality the test aims to assest how it works practically. Practitioners test the practicality test to find out how practical the products that have been designed are. To test the practicality of a product, the user can use a questionnaire that refers to the Kappa Cohen formula; on the results obtained, the kappa moment results will be obtained with the formula in the following equation [7].

$$
\kappa=\frac{\rho-\rho e}{1-\rho e}
$$

$\mathrm{K}$ : moments kappa which show practicality product

$\mathrm{P}_{\mathrm{o}}$ : The proportion that is realized, calculated by dividing the total value given by the examiner divided by the maximum number 
$\mathrm{P}_{\mathrm{e}}$ : The unrealized proportion, calculated by subtracting the maximum number of scores by the total number given by the examiner divided by the maximum number of scores

The effectiveness test is determined by the assessment of a questionnaire filled out by students. The results of the effectiveness test questionnaire were analyzed by referring to the statistical formula of Richard R. Hake (G-Score) as the following equation [7].

$<g>=\frac{(\%<S f>-\%<S i>)}{(100-\%<S i>)}$

Description :

$<\mathrm{g}>$ : G- Score

$<$ Sf $>$ : Final score

$<\mathrm{Si}>$ : Initial score

\section{Results and Discussion}

\subsection{Communication}

This stage consists of project initiation and requirements gathering activities. Requirements gathering includes defining user requirements, system requirements, brainware requirements, and technology requirements.

\subsection{Planning}

The design of a mobile-based e-sociometry application in the guidance and counseling laboratory of the Bukittinggi State Islamic Institute will distribute its duties to several roles, including admin/ officer and user. The planning stage in this research consists of estimating, scheduling, and tracking activities.

\section{3. $\quad$ Modeling}

\subsubsection{Use case diagram}

The use case diagram in this study is shown in Figure 1 below.

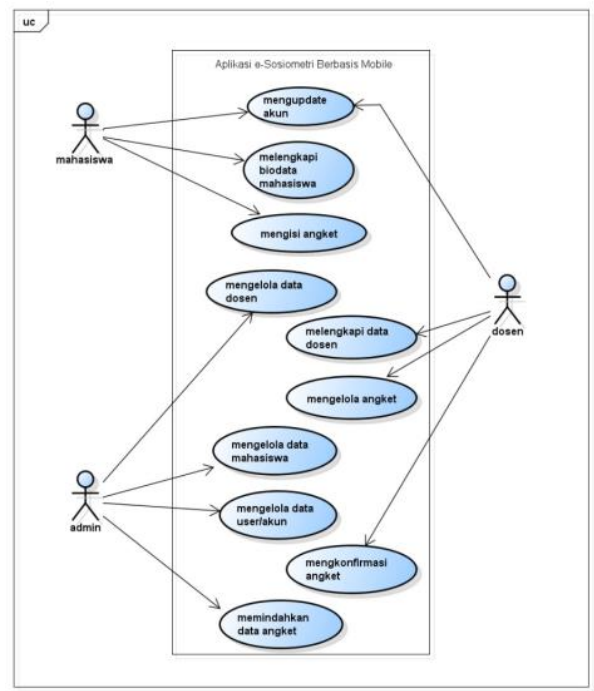

Figure 1. Use Case Diagram

\subsubsection{Activitiy diagram}

Activity diagrams in this study are shown in Figure 2, Figure 3, and Figure 4 below. 


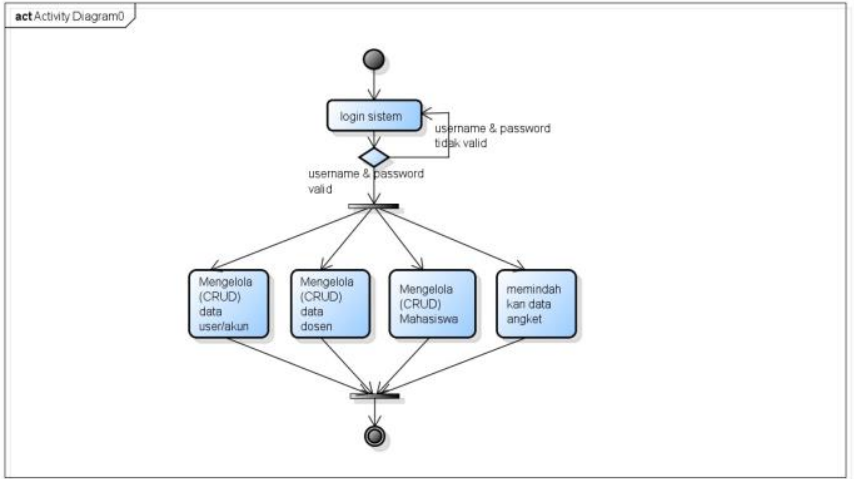

Figure 2. Admin Activity Diagram

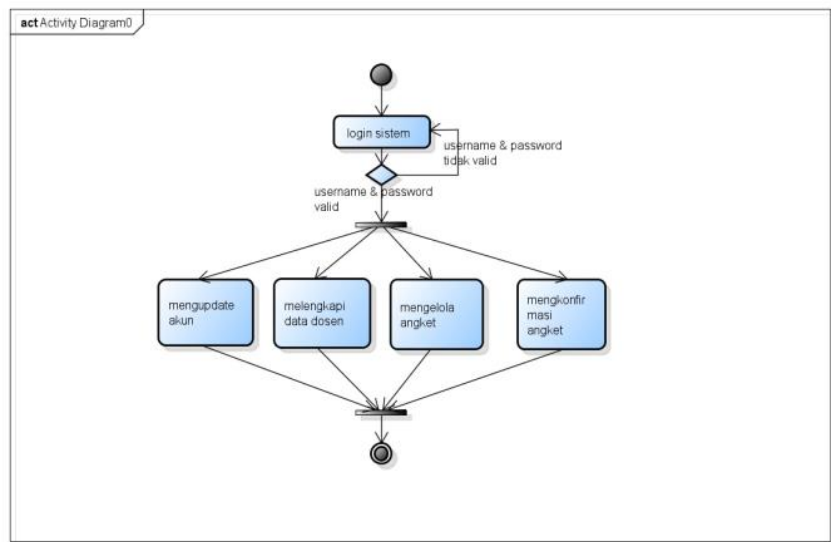

Figure 3. Lecturer Activity Diagram

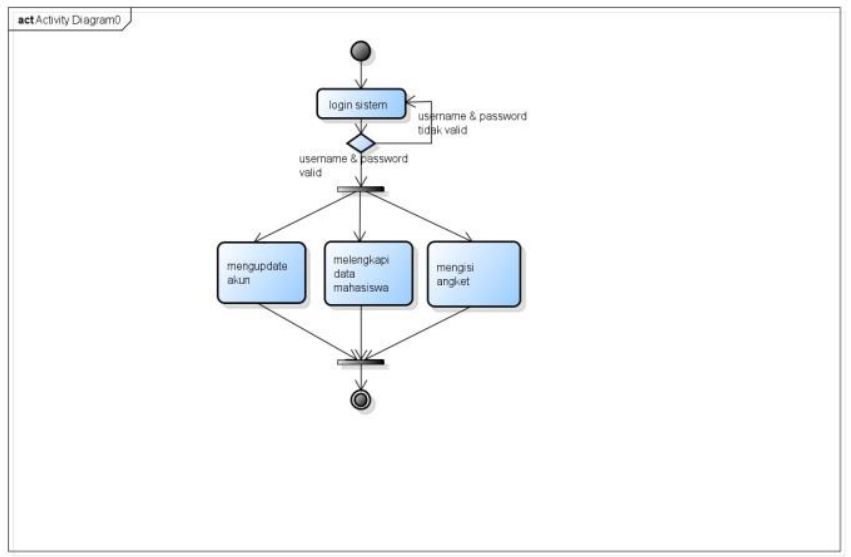

Figure 4. Student Activity Diagram

\subsubsection{Class diagram}

The class diagram in this study is shown in Figure 5 below. 


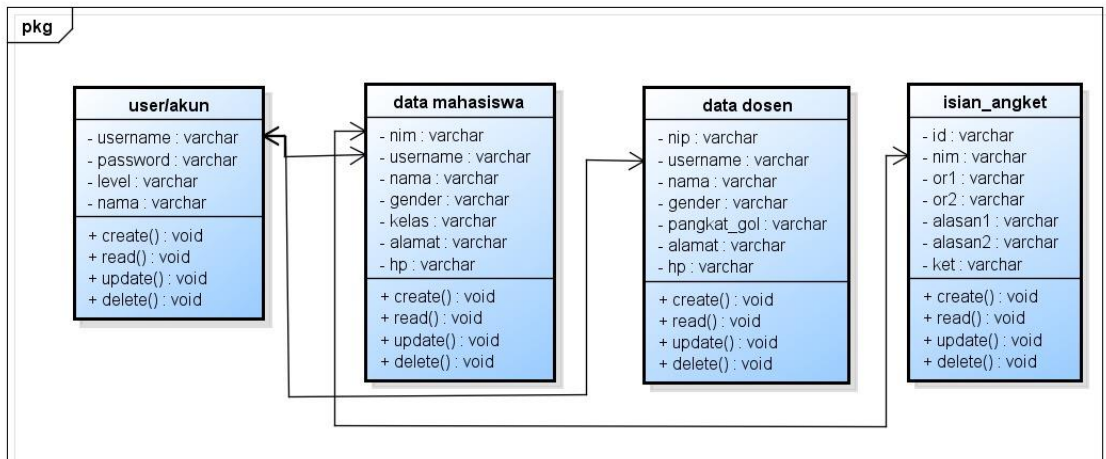

Figure 5. Class Diagram

\subsubsection{Sequence diagram}

The sequence diagram in this study is shown in Figure 6 below.

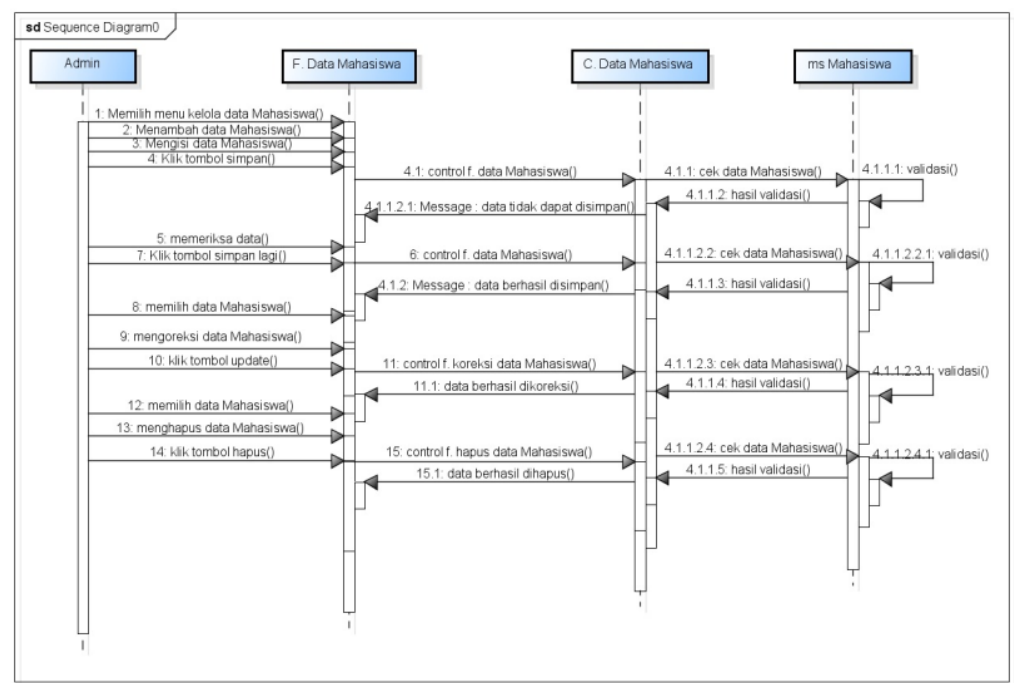

Figure 6. Sequence Diagram

\subsubsection{User interface}

Before entering the application, you will be directed to the login screen as shown in Figure 7. Next, enter your username and password, either login as admin or user.

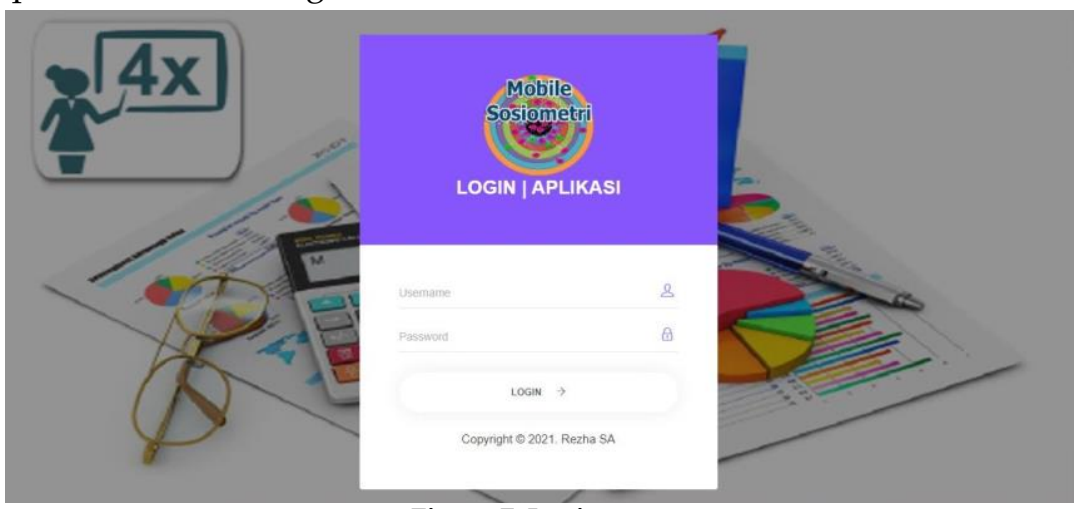

Figure 7. Login page

After the admin or user logs in, the start page will appear, for the admin and user start pages have the same appearance because the initial page display contains an explanation of sociometry, what distinguishes it later is the dashboard section. Figure 8 below is the initial page view. 

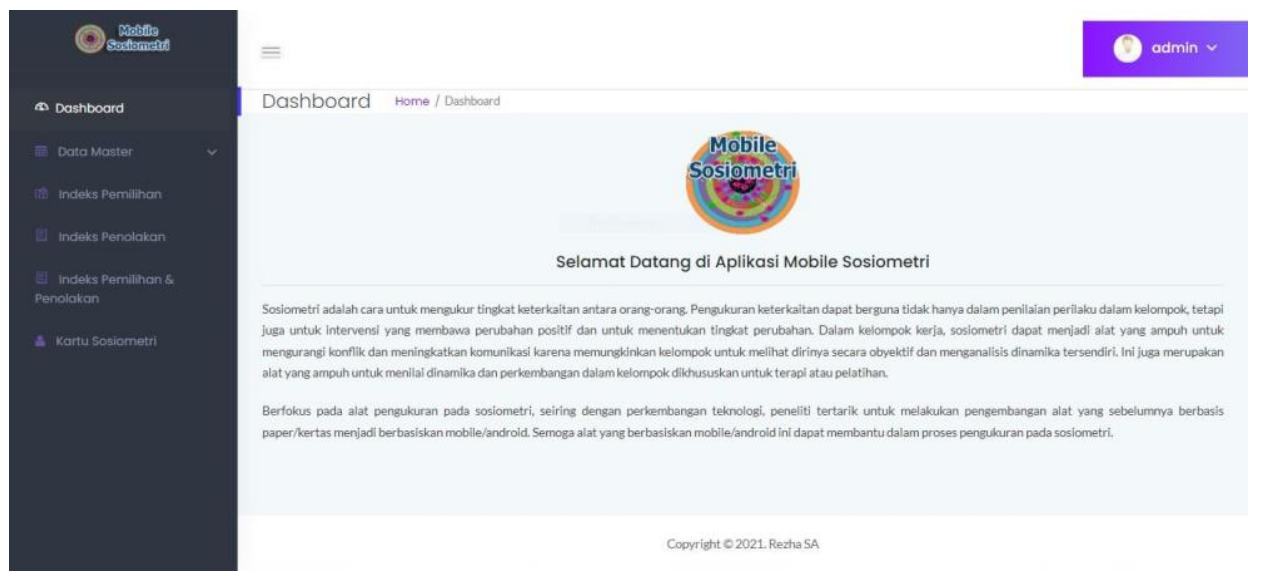

Figure 8. Dashboard Page

The admin dashboard display consists of several options, namely master data (student data, class data, and user account tables), selection index, rejection index, selection and rejection index, and finally a sociometric card. As in Figure 9 below.

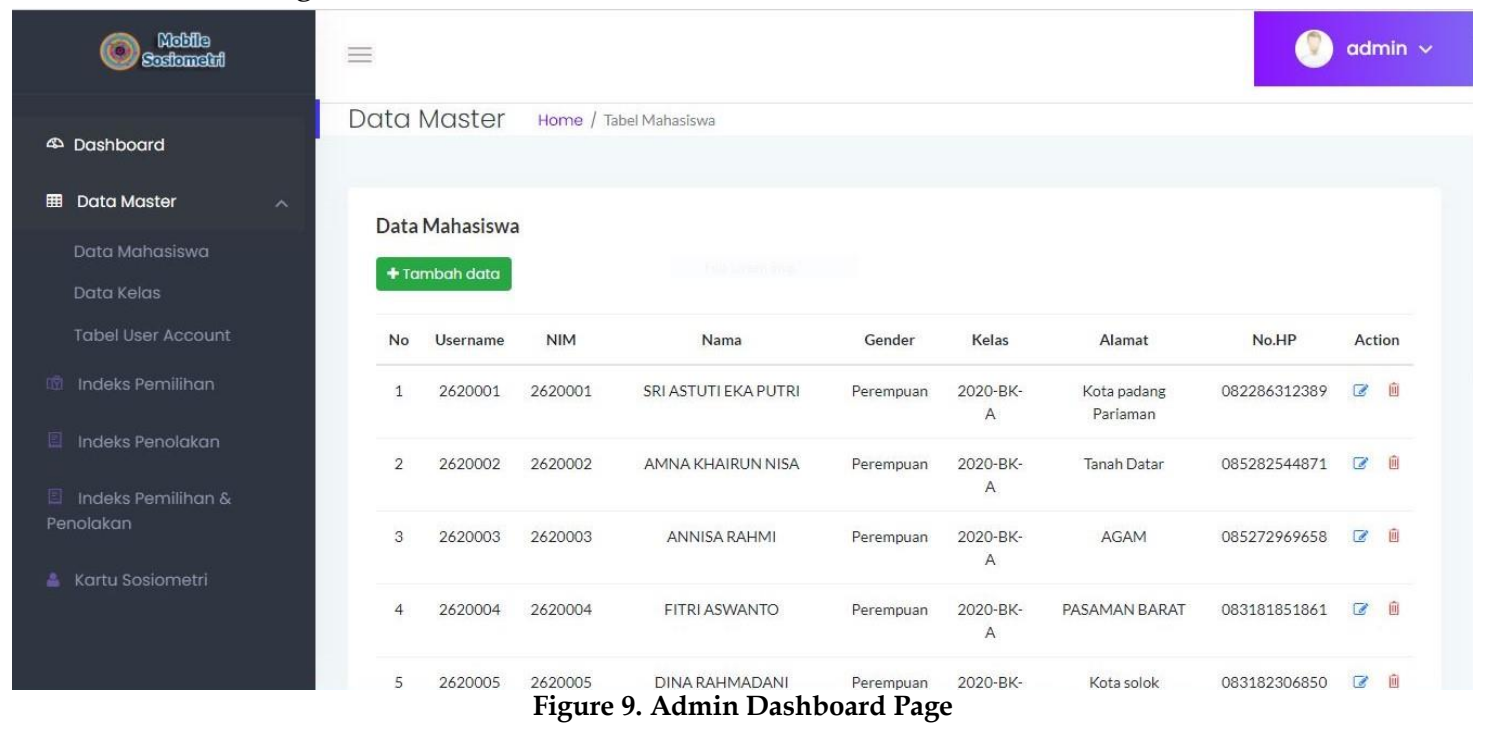

Next is the selection index chart, the rejection index chart, the selection and rejection index chart. In this graph display, the difference is that the selection index graph will be marked in green while the rejection index graph is marked in red, and the selection and rejection index graph will display both charts as a whole. As in Figure 10, Figure 11, and Figure 12. 


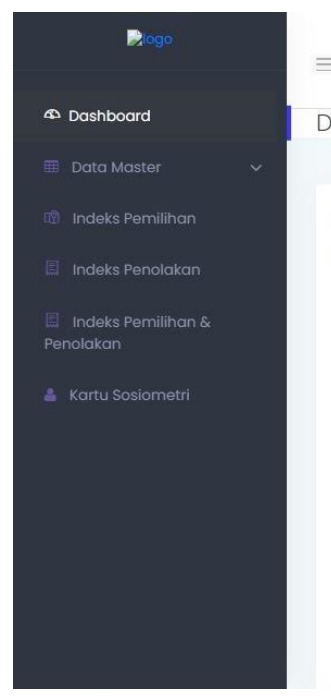

$\equiv$

Data Master Home / Tabel Grafik Indeks Pemilihan

Progress Table

Kelas: 2020-BK-A

\begin{tabular}{|c|c|c|c|c|c|}
\hline No & NIM & Nama & Gender & Skor & Grafik Skor \\
\hline 1 & 2620002 & AMNA KHAIRUNNISA & Perempuan & 3 & - \\
\hline 2 & 2620003 & ANNISARAHMI & Perempuan & 0 & \\
\hline 3 & 2620005 & DINARAHMADANI & Perempuan & 2 & - \\
\hline 4 & 2620008 & FARNIDATULARENA & Perempuan & 1 & $=$ \\
\hline 5 & 2620004 & FITRIASWANTO & Perempuan & 0 & \\
\hline 6 & 2620006 & LAFZIATUL SASRIZA & Perempuan & 0 & \\
\hline 7 & 2620009 & LUTHVITACRISHANTI SAUSAN & Perempuan & 1 & - \\
\hline 8 & 2620029 & MUHAMMAD NUR & Laki-laki & 1 & - \\
\hline
\end{tabular}

Figure 10. Graph of Selection Index
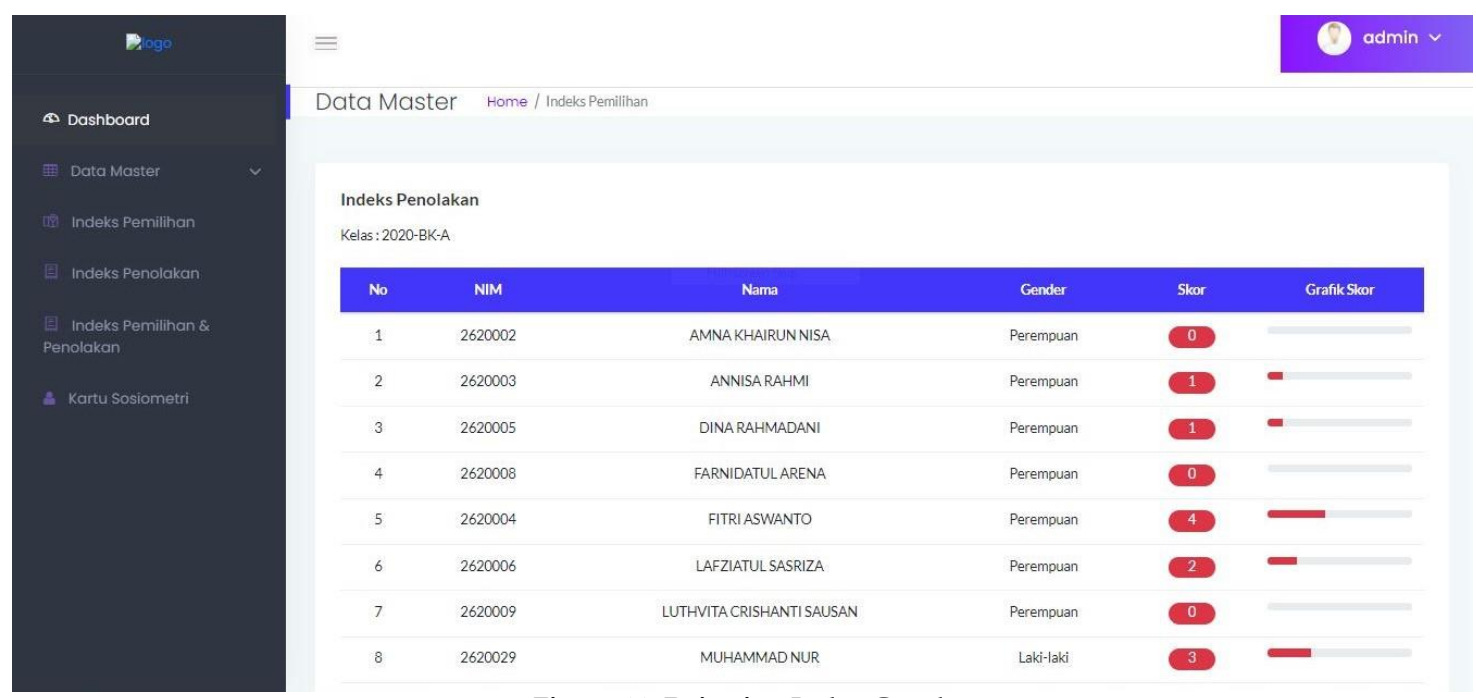

Figure 11. Rejection Index Graph

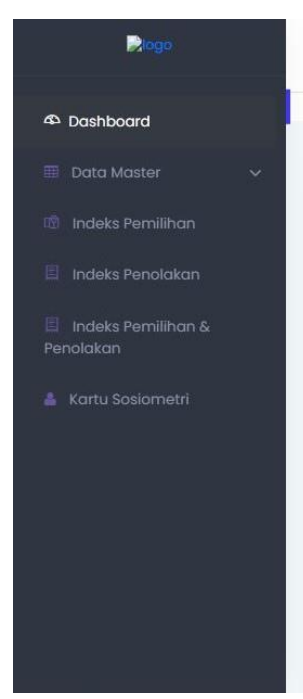

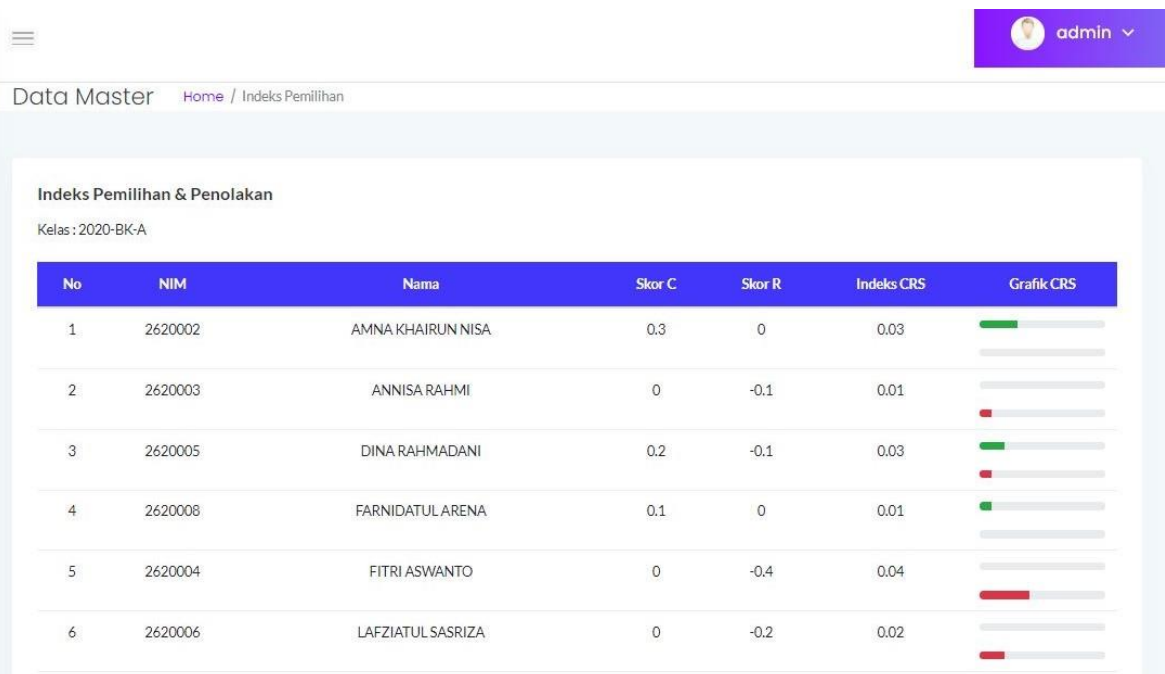

Figure 12. Graph of Selection and Rejection Index 
In the user section there are two menu options on the dashboard, the first is about filling out sociometric questionnaires and the second is about instructions for using the application. As in Figure 13 below.
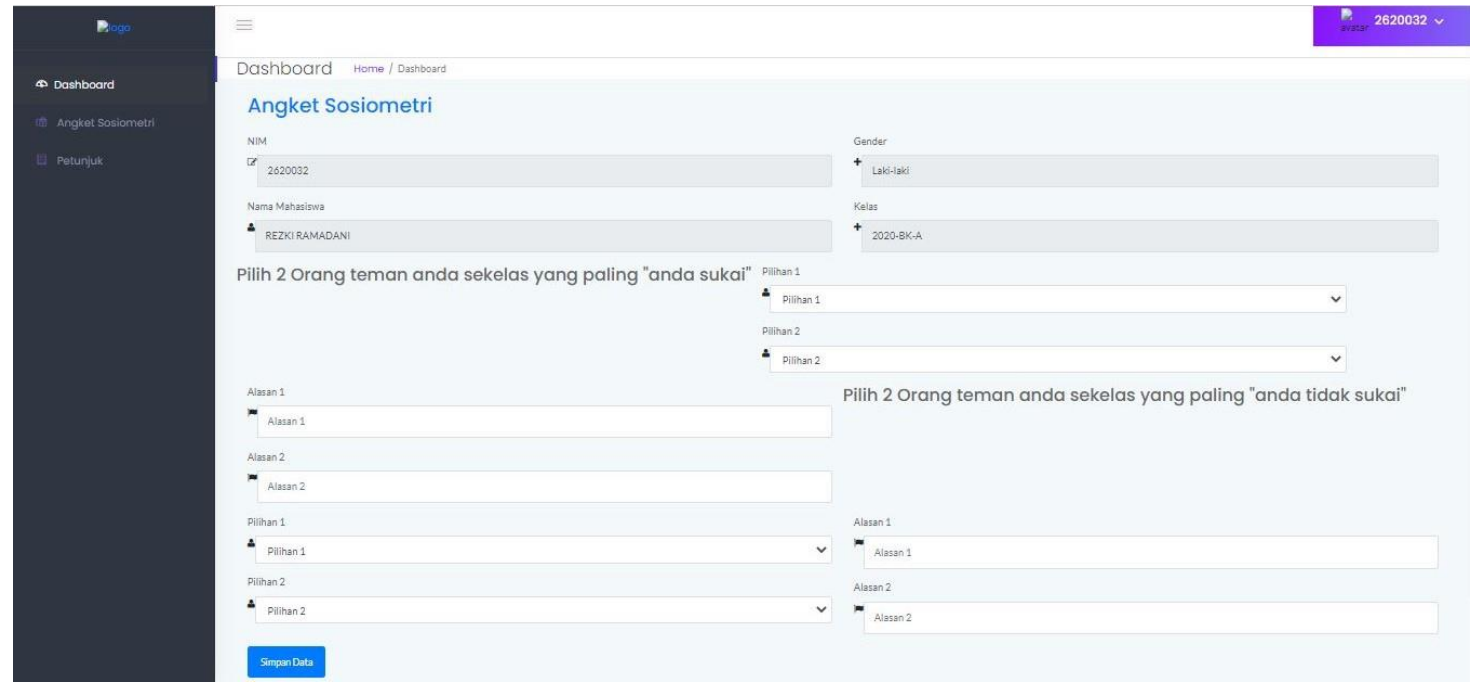

Figure 13. Sociometric Questionnaire

\subsection{Construction}

Construction is done by translating the design into a programming language. At this stage, the program coding for connecting menu items and displays along with a mobile-based e-sociometry application database is carried out.

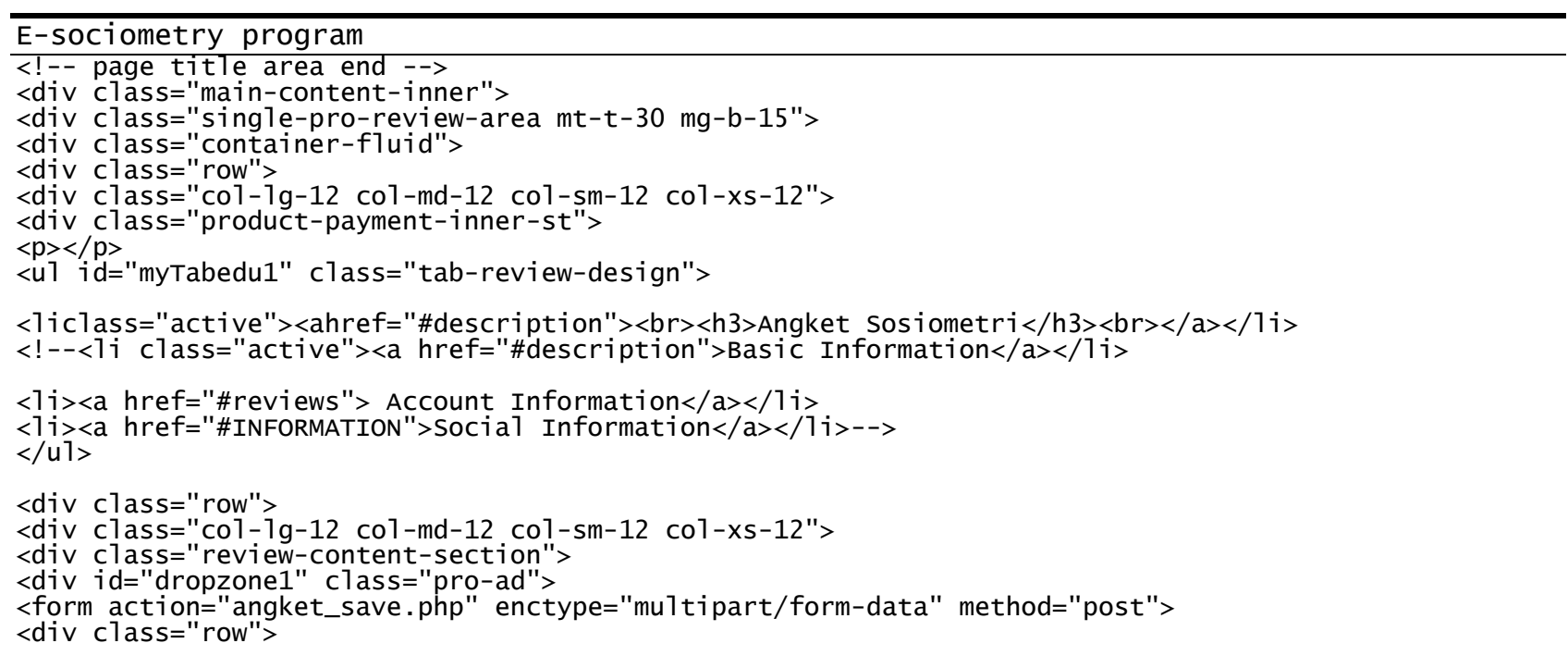

\subsection{Deployment}

After the e-sociometry has been designed, it is then distributed to users to be applied. The maintenance process is carried out if the application experiences problems in its operation.

\subsection{Product Test}

Product validity testing was carried out on three experts and got a final score of 0.85 with valid criteria. While the practicality test was carried out on three practitioners with a final score of 0.83 , which means it is very practical. The effectiveness test was carried out on ten students with a final result of 0.75 which means the application has a high effectiveness. 


\section{Conclusion}

Based on the research that has been done, the authors conclude that the authors have succeeded in designing a mobile-based e-sociometry application at the Counseling Guidance Laboratories of the Bukittinggi State Islamic Institute that is valid, practical, and effective. According to Pressman, the development of this mobile-based e-sociometry application was designed using Research and Development (R\&D) research using the Waterfall model SDLC development model, which consists of stages, namely Communication, Planning, Modeling, Construction, Development which can assist in facilitating counseling and guidance services. in the implementation of non-sociometric test instruments.

The product validity analysis test results from the three validators showed that the value of product validation using the Aiken's V statistic formula was 0.85 with valid criteria from aspects of content validity, instructional design aspects, appearance, and linguistic aspects. However, there are also comments and suggestions from validators related to the e-sociometry application that the author must improve to make it even better. The Practicality Test of three people who did the product practicality test obtained a value of 0.83 with very practical criteria. And for the effectiveness test, it was obtained based on the product effectiveness sheet with a value of 0.75 , which was declared to be very effective.

\section{References}

[1] M. Q. Shihab, “Wawasan Al-Qur'an Tafsir Maudhu'I atas Pelbagai Persoalan Umat," Wawasan Al-Qur'an Tafsir Maudhu'I atas Pelbagai Persoalan Umat, vol 4, no.2, November, p. 453, 2016,

[2] I. Laila, "Penafsiran Al-Qur'an Berbasis Ilmu Pengetahuan," Epistemé J. Pengemb. Ilmu Keislam., vol. 9, no. 1, 2014, doi: 10.21274/epis.2014.9.1.45-66.

[3] H. Habe and A. Ahiruddin, "Sistem Pendidikan Nasional," EKOMBIS SAINS J. Ekon. Keuang. dan Bisnis, vol. 2, no. 1, pp. 39-45, 2017, doi: 10.24967/ekombis.v2i1.48.

[4] Y. Yusri and F. Meivilona, "Pelatihan Pemanfaatan Program Analisis Sosiometri dalam Pelayanan Bimbingan dan Konseling bagi Konselor Pendahuluan Metodologi Hasil," no. Dcm, pp. 16-19, 2012, doi: 10.24036/4.115.

[5] M. Yuliansyah and M. Herman, "Teknik Sosiometri Dalam Asesmen Pelayanan Konseling Pada Kepala Sekolah Dan Guru Sdn Kuin Selatan 1 Banjarmasin," J. Bimbing. Dan Konseling Ar-Rahman, vol. 4, no. 1, p. 25, 2018, doi: 10.31602/jbkr.v4i1.1453

[6] W. P. Sari and R. Okra, "Perancangan Aplikasi Mobile Penyetoran Ayat Untuk Mahasiswa Komprehensif di IAIN Bukittinggi Berbasis Android," J. Ilm. Inform., vol. 5, no. 2, pp. 157-167, 2020, doi: 10.35316/jimi.v5i2.957.

[7] Q. U. R. An, “Penalti Untuk Guru Di SMP Tahfizhul," vol. 12, no. 3, pp. 150-160, 2020.

[8] M. R. Darmawan and H. A. Musril, "Perancangan Sistem Pendaftaran Audiens Seminar Proposal di Institut Agama Islam Negeri (IAIN) Bukittinggi," J. Teknol. dan Inf., vol. 11, no. 1, pp. 26-39, 2021, doi: 10.34010/jati.v11i1.3346.

[9] T. A. Farma and R. Okra, "Pengembangan Aplikasi Pembayaran dan Didukung oleh Pesan WA Sebagai Notifikasi Pembayaran di SMA INS Kayutanam," JSTIE (Jurnal Sarj. Tek. Inform., vol. 9, no. 1, 2021, doi: 10.12928/jstie.v1i1.17363. 